\title{
Concealing in the Public Interest, or Why We Must Teach Secrecy
}

\section{Susan Maret ${ }^{1}$}

\begin{abstract}
Secrecy as the intentional or unintentional concealment of information is the subject of investigation within the humanities, social sciences, journalism, law and legal studies. However, the subject it is not widely taught as a distinct social problem within higher education. In this article, I report personal experience with developing and teaching a graduate level course on a particular type of secrecy, government secrecy, at the School of Information, San Jose State University. This article includes discussion on selecting course materials, creating assignments, and navigating controversial histories. This article also sets the stage to this special issue of Secrecy and Society on the subject of teaching secrecy.
\end{abstract}

\section{Keywords}

archives, censorship, citizenship, confidentiality, epistemic communities, government publications, government secrecy, higher education, information policy, information studies, interdisciplinarity, Library and Information Science, objectivity, openness, privacy, secrecy studies, social problem, sociology of knowledge, teaching, transparency, US history

Secrecy - what diplomatically is called "discretion," as well as the arcane imperii, the mysteries of government and deception, the deliberate falsehood and the outright lie used as legitimate means to achieve political ends, have been with us since the beginning of recorded history. Truthfulness has never been counted among the political virtues, and lies have always been regarded as justifiable tools in political dealings. (Arendt 1972,4)

1 Maret is a lecturer at the School of Information, San Jose State University and managing editor of Secrecy and Society. 
Secrecy, or the intentional or unintentional concealment of information, is generally considered a problem within social relationships. A particular kind of secrecy called administrative, or government secrecy, became highly institutionalized in the US with the Cold War and founding of the national security state. This type of secrecy, of note for its focus on control of information within government bureaucracy, has implications for the freedom of the press, intellectual freedom, and public trust in policies. ${ }^{2}$ As philosopher Sissela Bok (1989 [1983]) tells us,

Because official secrecy allows governments to deceive and manipulate public opinion without any accountability whatsoever, it cuts at the very roots of democracy. It prevents citizens from perceiving and debating the issues, and often gives a false sense of their simplicity, suggesting all is fine when it is not. (249)

In 2006, I was invited to develop a course on secrecy at the School of Information, San Jose State University. ${ }^{3}$ This invitation presented an opportunity to introduce future information professionals, including those federal librarians and archivists, to the social problem that is concealment and restriction of information. ${ }^{4}$

2 Or as described by Max Weber, briefly, the dominant form of social organization in the rationallegal society, and usually hierarchically organized. As Weber pointed out, bureaucracies are of note for their emphasis on keeping knowledge and intentions concealed ("secret sessions"). Types of bureaucracies may be government, intergovernmental, and corporate. See Weber's essay "Bureaucracy" in H. H. Gerth \& C. Wright Mills' From Max Weber: Essays in Sociology, (New York: Oxford University Press, 1946). See also David Graeber's The Utopia of Rules: On Technology, Stupidity, and the Secret Joys of Bureaucracy (Brooklyn:Melville House, 2015).

3 A thank you to Dr. Linda Main, School of Information, San Jose State University, who recognized the critical significance of such a course and invited me to develop and teach information secrecy starting in 2006-2007.

4 There are many definitions of the social problem. Best (1995) observes that "social problems are trouble spots within society-social arrangements that do not work properly" (3). In this article,however, I understand a social problem as a "social condition that a segment of society demonstrates to be significantly harmful to members of society and in need of a remedy. The definition is relative, and is informed by larger social values that shape the way we understand 
Before I begin my discussion on the secrecy course, I want to own up that at times, this article is anecdotal and personal. To this, I argue that as teacherscholars, our encounters with history, theory, and social conditions inform our choices as to what we include in the courses we teach and what we choose to omit. For me, these choices are compatible with historian Thomas L. Haskell's (1998) concept of objectivity, or "something entirely distinct from detachment, fairness, and honesty, but the product of extending and elaborating these priceless and fundamentally ascetic virtues" (149-150).

Let me also refer readers to the literature on qualitative social science methods, which reveal I-Writing (e.g., Paley 2001), first hand and metacognitive accounts, narratives (e.g., Gudmundsdottir 1995; Watts 2008), storytelling (Gerbner 1988; Jackson 2013), and autoethnography are powerful tools in which to position oneself in relation to discovering and sharing knowledge (e.g., Pitard 2017). For this article, and generally the special issue of Secrecy and Society on teaching secrecy, these methodologies suggest that sharing of experience has onthe-ground validity in teaching and researching matters of upmost societal concern.

What follows in my discussion is what I brought to the development of government secrecy course. I share personal experience with secrecy, report on the selection of course materials, how the course evolved in response to changes in information policy over presidential administrations, and ways of supporting students as they encounter new histories and perhaps uncomfortable knowledge. 


\section{The Experience of Secrecy}

My encounters with concealment and restriction of information - as a manifestation of formal and informal rules around control of information - deeply influenced the development of the secrecy course. These complementary experiences can be distilled to the following: a former life as an academic librarian, service with a national environmental organization, and doctoral research.

As a librarian, I worked with "open" (public) documents published through Government Printing Office (GPO) and made available as part of the Federal Depository Library Program (FDLP). ${ }^{5}$ These documents, or government publications as defined in the U.S. Code 44 U.S.C. 1901, are "informational matter which is published as an individual document at Government expense, or as required by law."6 But not all government publications are indeed "public" in the sense of flowing through GPO and FDLP to libraries and organized for future discoverability. ${ }^{7}$ Those documents that fail to make it into the commons, either due to arrangements with corporate publishers that place copyright restrictions on public information (e.g., declassified documents), institutional failure to adhere

5 Established by Congress in 1860, GPO has responsibility for printing, distribution, and sale of government publications. Generally speaking, the FDLP makes government publications available through libraries that join the program.

6 A report by the Federal Research Division (2018) interestingly uses the term "public information products."

7 See DiMario (1997), who notes that agencies may also bypass the depository system by way of language in 44 U.S.C. 1903 that permits publications to be excluded from the FDLP if they are "so-called cooperative publications which must necessarily be sold in order to be selfsustaining." 
to mandates regarding publication, and/or ignorance of directives, are missing. ${ }^{8}$

Missing information is perhaps on the same footing as intentional or unintentional concealment, and suggestive of sociologist Georg Simmel's (1906) observation that secrecy makes possible "a second world." This second world, as Simmel explains, is based in the secret, which "offers the possibility of a second world alongside the manifest world... where the latter is decisively influenced by the former" (Wolff 1950, 330).

As it pertains to government secrets, this second world is composed of certain techniques and institutionalized practices that "secure" information, such as the classification system and markings. There are numerous other restrictive information policies, including irregularly publishing agency information and failing to preserve or record information (Maret 2018). In the 21st century, it sadly holds true that the US is "a nation of stampers, leakers, and shredders. Worse than that, in the new computer era we inhabit, a simple delete button pressed hard and long erases any controversy, any issue of state the state seeks to erase" (Cook 1996, 285). ${ }^{9}$ It is indeed startling to think of government

8 Or fugitive, which Lerud and Dunn (1997) define as "information that is difficult to identify despite informed use of standard indexes and bibliographic databases, or is difficult to acquire through standard publishing channels." Missing - fugitive - might also fall into the grey literature, or the "manifold document types produced on all levels of government, academics, business and industry in print and electronic formats that are protected by intellectual property rights, of sufficient quality to be collected and preserved by libraries and institutional repositories, but not controlled by commercial publishers; i.e., where publishing is not the primary activity of the producing body" (Schöpfel 2010). Information buried in federal and state permits and vast amounts of pages declassified and released by FOIA are instances of missing-fugitive-grey. Moreover, missing-fugitive-grey may occur through poor organization of information (e.g., lack of indexing, inadequate finding aids, poor subject headings and database design) and hard to read regulations, congressional bills, publicly funded research, budgets, and annual reports, where vital information is buried. See also Jacobs (2019) who discusses additional "classes of fugitives" not distributed by GPO.

9 Case in point, the Advisory Committee on Human Radiation Experiments (ACHRE), formed during the Clinton administration, reported on the Atomic Energy Commission's 1947-1948 
information in this way, as missing and conditional, where practices and policies concerning secrecy and restriction of information co-exist with open access and a certain amount of transparency is built into governance.

In the context, I've come to think of government information as open, closed, and twilight. For typologies of open and closed information we look to Forrester's $(1965,51)$ work in cybernetic theory. Open information is just that, select information that flows from libraries, federal agencies, the press, and Internet. It is open, or public, in the sense that it does not violate official secrets and is approved for public dissemination. Closed information is associated with a specific level of access and privilege. Information will either never be made public or become known decades later. Closed information is associated with "the right of an individual to see or use a particular type or level of classified information which is dependent on a need to see or know" (Cohen 2000, 2). I extend closed (or missing) here to those documents that are classified under numerous federal laws, executive orders, and presidential security directives (e.g., Reagan, Clinton) and memoranda (e.g., Nixon, Trump). Twilight information, on the other hand, "lies somewhere between deep concealment and full disclosure" (Thompson 1999, 186). Remarks made by former Sen. John Kerry (1997) and Cook (1996) are examples of twilight information in terms of the half-knowing that results from redacted, declassified documents; while redaction suggests disclosure, openness, publicity, and transparency, it also concerns uncertainty.

decision to keep nuclear test data secret: "information on fallout data gathering appears to have been classified out of concern that public opinion (in the United States, but also elsewhere) might imperil U.S. weapons development programs." See Chapter 13 "The Practice of Secrecy," https://bioethicsarchive.georgetown.edu/achre/final/chap13.html. 
Work with a national environmental organization deepened my understanding of access to government information and its relationship with secrecy. ${ }^{10}$ This work focused on the legacy of weapons waste and entailed laboriously combing through declassified Department of Defense documents and those materials produced as part of the Environmental Protection Agency's (EPA) Administrative Record under the Comprehensive Environmental Response, Compensation, and Liability Act (CERCLA, commonly referred to as Superfund). The Administrative Record, established by EPA as an essential part of Superfund's regulatory framework, is a living archive of a site's pollution history and central to the selection of response actions, selection of cleanup remedies, and public health. Many documents contained in Administrative Record, including declassified materials, correspondence, contractor reports, and state and local oversight documents are missing (or fugitive, grey) in the sense of not being organized for discoverability or being widely available to citizens and regulators. In doing this work, the Freedom of Information Act (5 U.S.C. § 552) became a necessary investigatory tool. In filing requests, I unraveled the multi-faceted recordkeeping practices of federal agencies and descended into states of intersecting, overlapping secrecy, each with their own statutory origins and historical and cultural contexts.

It was in my doctoral program, however, where I interviewed citizens representing a variety of environmental issues, that the fallout from secrecy raised complex questions about access to information, information seeking, risk, 
and informed consent. As Marcus G. Raskin and Robert Spero (2007) observe, "trying to get information from the bureaucracy, whether federal, state, or local, is an enervating task, and some people simply give up trying" (118). My research bore this out. In following this trail, environmental right to know meshed with environmental justice to reveal several problems: a continuing reliance on natural security secrecy, and on one former chemical weapons manufacturing site, failure to communicate and reduce risk to "contaminated communities," protect resident species, and mitigate pollution. ${ }^{11}$ Through this research, I was confronted with the institutional system that is US government secrecy, and with it, decades of failure to tell the truth to workers and the public regarding risk from offsite pollution and accidents. This situation testifies to Arthur Schlesinger's $(1973,356)$ observation that government assumes it has the right to lie; what then follows is that if information is power, the ability to distort and control information will be used more often than not to preserve and perpetuate that power (Wise 1973, $343) \cdot .^{12}$

These interconnected experiences were the foundation for creating a course dedicated to government secrecy and remain a rich source of inspiration and knowledge.

11 See my Why We Need Good Information to Cleanup Bad Places, which uses the former chemical weapons manufacturing facility Rocky Mountain Arsenal to document the utter complexity of information sources produced via the Superfund process, including that of "recycling" information: https://rockymountainarsenalarchive.files.wordpress.com/2011/07/sm whyweneedgoodinfo.pd f

12 See Edelstein's (2018) insightful Contaminated Communities: Coping with Residential Toxic Exposure (New York: Routledge). Edelstein focuses on community informatics in what he terms "contaminated communities," or those communities impacted by pollution, disaster, uneven information flow, and cleanup technologies that pose risk. I am grateful for this model. See also the Final Report of the Federal Facilities Environmental Restoration Dialogue Committee with its Principles of Environmental Cleanup of Federal Facilities, April 1996, https://nepis.epa.gov/. 


\section{A Passion for Secrecy: Conceptualizing the Course and LIS}

Developing a graduate course on secrecy, specifically government secrecy, presented a challenge. At the time, a review of course catalogs did not find such a course was taught in institutions of higher learning. ${ }^{13}$ I found this situation puzzling, for post-9/11, critical development of special topic courses were a response to the assault on civil liberties and emerging view of information rights as human rights. ${ }^{14}$ I found it perplexing - and still do - that no standalone course exploring the interdisciplinary nature of secrecy, particularly government secrecy, is widely offered within higher education, particularly within LIS (Library and Information Science) as a discipline within the social sciences.15

To wit, secrecy, closely associated with censorship and an affront to intellectual freedom, should be of supreme importance to LIS professionals as they teach interlocking literacies and provide research support across social institutions (Maret 2014a). Secrecy, which "undercuts the possibility of peer review and oversight" (Friedrich 1972:21), has clear significance for this profession as concealment has the potential to impair research integrity and the advancement of knowledge.

Historically, the LIS profession's critique of secrecy and its close cousins

13 Although discussion of restriction and concealment of information might be covered within a course.

14 I developed and taught a unique course titled Privacy in the Age of Terrorism in the Department of Political Science, University of Colorado, Denver in 2004. The course examined civil liberties in the context of privacy, secrecy, and national security.

15 I consider LIS an academic member of the social sciences; see also Steve Fuller (2007), who writes that "interdisciplinarity turns out to be the main internal motivator of sustained epistemic change: today's disciplines were born interdisciplinary, as social movements that aspired to address all manner of phenomena and registers of life, not simply the domain of reality over which they came to exercise custodianship" (21). 
(e.g., censorship, privacy, surveillance) is notable. For example, the American Library Association's (ALA) multi-volume historical Less Access to Less Information By and About the U.S. Government illustrates the hidden corridors of secrecy, and library professionals' testimony reported in the 1987 Hearing on Sensitive But Not Classified Information was a response to censorship and secrecy vis-à-vis the Reagan administration's NSDD-145 (National Commission on Libraries and Information Science 1988 [1987]).16 The profession's energetic reaction to surveillance during the years of the FBI's Library Awareness Program (Foerstel 1991; McDonald 2011; Starr 2004) and Section 215, USAPATRIOT Act privacy violations (McDonald 2011) are well documented; numerous resolutions drafted by ALA roundtables are a defense of intellectual freedom and the freedom to read and conduct research. In this regard, the LIS profession brought to light that "conflicts over secrecy are conflicts over power, and more importantly, power over controlling the flow of information" (Bok 1989 [1983]).

On August 13, 1813, Thomas Jefferson wrote to Isaac McPherson regarding what we tend to think of in contemporary times as intellectual freedom:

That ideas should freely spread from one to another over the globe, for the moral and mutual instruction of man, and improvement of his condition, seems to have been peculiarly and benevolently designed by nature, when she made them, like fire, expansible over all space, without lessening their density in any point, and like the air in which we breathe, move, and have

16 Reagan's NSDD-145 authorized the National Security Agency (NSA) to control the dissemination of government, government-derived, and non-government information that might adversely affect "national security." This policy had a powerful impact on librarians and the public sphere who argued that national security classification already existed to protect sensitive (but unclassified) information. Representatives from the LIS profession such as Christie Vernon (American Library Association), Sandy Morton (Special Libraries Association), Sandra K. Peterson (Government Documents Roundtable), and Miriam Drake (Association of Research Libraries) testified as to the impact of NSDD-145 on scientific and technology-transfer related information that openly resides in public libraries, databases, and commercial information products. 
our physical being, incapable of confinement or exclusive appropriation.17

Thomas Jefferson's fire is reduced to a pale flame with expansive use of government secrecy. Post-September 11 and other crimes, researchers, professionals, and citizens must be prepared for the obvious challenges to the flow of information (e.g., reauthorized USAPATRIOT Act's National Security Letters, NSA bulk collection, pandemic surveillance, restriction of federal/state/local records and government reports on energy and climate) and the subtle ways that diminish intellectual freedom and align secrecy with censorship, lies, conspiracy, and deception (e.g., redaction, silencing of federal scientists, secret databases, agency budgets, "Congress's library of secret law"18, agency opinions, memoranda, and letters19, overclassification, delayed history due to classification, prepublication review20).

Nick Moore (1998) notes that in addition to civil, political, and social rights, there exists a fourth set of rights "we can call intellectual rights." Intellectual rights, according to Moore (1998), are those rights that citizens require in order "to function effectively within a state that is increasingly sophisticated and more and more reliant on information." 21 These informational rights include citizen

17 This specific correspondence between Jefferson and McPherson suggests the right of intellectual property, e.g. patents, but I interpret this passage broadly in terms of information access, freedom of expression, and right to communicate. The letter is found at https://founders.archives.gov/documents/Jefferson/03-06-02-0322.

18 See Rudesill 2015.

19 Gotein 2016; Raskin and Spero 2007.

20 Many books purchased by libraries have undergone prepublication review. It critical for librarians and the public to understand the process and its role in secreting and protecting information and those seminal cases such as Snepp v. CIA.

21 See Janoski and Gran (2002, 15-16) who note that freedom of information is a political right of citizenship. I diverge from their idea in that freedom of information is dependent on where you live on the planet, and it is also a legal and social right. 
responsibility to be "well informed" (Moore 1998). We can conjecture here that "well informed" and indeed "informed" have their roots in Jefferson's Enlightenment understanding "to include thoughtfulness, ethical soundness, and good judgment as well as factual information" (Yankelovich 1991, 245). But here well-informed and informed assume publicity, openness, and transparency, which are compromised under regimes of concealment, even if secrecy is used for functional, or positive reasons.22 Well informed and informed cease to be an ideal without the social will to support a full range of information seeking, education, libraries, and investigatory journalism, which enable individuals to repel the forces of secrecy and post-truth, the latter a chaotic climate where facts and evidence are disingenuously worked over for advantage and to deceive. 23

But where to begin with a government secrecy course? In constructing the course from the ground up, I realized it had to be structured as an exploration into information policies, politics (as the study of power), social theory, historical choices, and lost narratives. Moreover, the course must highlight the following question: "how are the citizens to keep a check on the state when the state shares its secrets with very few in positions of power and more often than not excludes the elected representatives of the people?" (Raskin and Spero 2007, 286). I dug into the literature of secrecy across fields and disciplines, then sketched a course description:

Information Secrecy and Freedom of Information. This course covers

22 See Friedrich (1972) in his Pathology of Politics.

23 Oxford Dictionaries, "'relating to or denoting circumstances in which objective facts are less influential in shaping public opinion than appeals to emotion and personal belief." See https://languages.oup.com/word-of-the-year/2016/. Also see Tesich (1992) who coined "posttruth." 
theoretical perspectives, history, policy, and cases relative to US government secrecy. Included in this course are case studies that range from the Presidential Records Act, the Freedom of Information Act, open records legislation, and security classification/declassification of government information.

Several years into teaching the course, I realized that titling the course "information secrecy" was redundant, for in some way, all secrecy concerns information.24

\section{The Course}

The course went through numerous iterations as I came to understand the machinery of secrecy by way of the scholarly literature, FOIA requests, institutional ethnography, and current events. As it evolved, and my thinking with it, the course became an exploration into the scholarship of national security/security studies and Foucault's governmentality, or "modern form of power called government," which deals with issues of state security, techniques of control, and new forms of knowledge (Darier 1999). ${ }^{25}$ "Democratic secrecy" is the philosophical anchor for the course. In a finely tuned argument, this type of secrecy, framed by Dennis F. Thompson (1999) as conflict, suggests "some of the best reasons for secrecy rest on the same democratic values that argue against secrecy" (182). Moreover, democratic secrecy concerns conflict over "the basic dilemma of accountability" as

democracy requires publicity (transparency), but some democratic policies require secrecy. A vicious circle arises in that citizens require information to in which to hold officials accountable, and to participate in various democratic activities; but some policies, if revealed, would jeopardize

24 And data, information, and knowledge.

25 See Dorothy E. Smith's (2005) Institutional Ethnography: A Sociology for People. Walnut Creek: Alta Mira Press. 
outcomes...this dilemma of accountability may be thought of as a political version of the Heisenberg uncertainty principle. $(182)^{26}$

When first designing the course, I thought of it as a supplement to reference and government documents courses taught at most iSchools and in LIS programs. I now consider the course as an exercise in civic awareness (Table 1).

\section{Table 1. Civic Engagement}

Citizenship, as Daniel Yankelovich (1991) reports,

is treated like a passive form of consumer behavior...people fail at citizenship not because they are apathetic but because they do not think their actions or views make any real difference. We need to expand the notion of citizen choice now confined to elections to include making choices on the vital issues that confront us every day. (240)

It is no secret that Simmel's second world or the Moynihan Commission's parallel government exists; its visibility is often dependent on experience and degree of engagement with layers within layers of government. The teaching of secrecy, as I view it, brings to lights these layers and encourages a different kind of relationship with government that supplants "episodic" engagement (Stasavage 2020, 5).

Students come to secrecy course with varying knowledge of US history, understanding of federal government, and the complex nature of information policies that drive agencies nested within agencies. ${ }^{27}$ History reigns supreme in the secrecy course, and is the glue that links the past to contemporary human experience. As Italian historian Francesco Guicciardini wrote to his friend Niccolo Machiavelli:

26 I include support for this idea by way of additional readings. See essays, for example, by Blanton (Maxwell School of Syracuse University 2003), Reppy (1999), Roberts (2004), Scott (2013), and my various edited works.

27 Students are usually employed in libraries as paraprofessionals, seasoned LIS staff returning for their terminal degree, or come to the course from another profession. The MLS/MLIS is the terminal degree in LIS. 
My dear Machiavelli, I earnestly believe that only men's faces and the outward aspect of things change, while the same things reoccur again and again. Thus we are witnessing events that happened earlier. But the alteration in names and outward aspects is such that only the most learned are able to recognize them. That is why history is a useful and profitable discipline, because it shows you and allows you to recognize what you've never seen or experienced. (as quoted in Boucheron 2020)

The secrecy course has been offered as an 8,10 , and 16 week course at SJSU. No matter the length, I attempt to offer the course as a seminar. Each time I teach the secrecy course, I conduct an extensive, interdisciplinary review of the scholarly and popular literature (Table 2). I select foundational readings from the literature of secrecy scattered across fields and disciplines, including readings from Maret and Goldman's (2009) Government Secrecy: Classic and Contemporary Readings, and my various works when relevant (Maret 2011, 2014a, 2014b)..$^{28}$

\section{Table 2. The Interdisciplinary Nature of Government Secrecy}

The secrecy course includes discussion of the following:

- Definitions and language of secrecy

- History (missing and delayed, e.g., The Foreign Relations of the United States series, JFK records)

- Information rights, intellectual freedom, and civil liberties (e.g., Article 19, First Amendment, declassified documents, Sunshine Week)

- Information ethics

- Information policies such as classification/declassification, overclassification, security markings, freedom of information (e.g., FOIA, fugitive-grey literature)

- LIS/reference/research as it concerns missing-fugitive docs (e.g., databases, sources of declassified documents, archives) ${ }^{29}$

28 Including database reviews from The Charleston Advisor on terrorism databases and declassified documents databases and archives.

29 The works of LIS scholars Peter Hernon and Charles McClure discuss dimensions of secrecy and security classification. Lee Strickland, especially after the events of 9/11, discussed national 
- Political philosophy

- Theory (e.g., Simmel's positive and negative uses of secrecy, Weber on bureaucracy, epistemic communities, role of disasters and information control $)^{30}$

- US history (e.g., Framers, congressional investigations)

As students immerse themselves in the course materials, I encourage them to reflect on their personal experiences with concealment and control of information, especially when encountering Simmel, the sociologist of interaction. I remind students that both secret-keeping and secrecy "are social acts" (White 2000). The psychology research literature on secrecy is useful in this regard as it reinforces Simmel's psychological insight from his 1906 translated essay "The Sociology of Secrecy and of Secret Societies," especially concerning the conceptual tensions around reciprocal knowledge, trust, and distance in relationships. ${ }^{31}$ As philosopher Giorgio Agamben's (2009) exposé of secrecy illustrates, bound to the secret is separation ${ }^{32}$ :

The term "secret," (the Italian segreto), what is kept from knowledge or observation, hidden, or concealed, derives from the past participle of the Latin secernere, to separate or set aside, from se- apart and cernere- to distinguish or to sift... The secret then evokes at once the process of separation, the element that has been separated, and the decision on the separation. (285)

In the course readings list and lectures, I include primary and secondary

security, terrorism, and access to information. John Bertot and Paul T. Jaeger, for example, address transparency alongside e-government, ICTs, the Digital Divide, and public libraries. 30 As Popper (1962) notes, "it is the task of social theory to explain how the unintended consequences of our intentions and actions arise, and what kind of consequences arise if people do this that or the other in a certain social situation. And it is, especially, the task of the social sciences to analyse in this way the existence and the functioning of institutions (such as police forces or insurance companies or schools or governments) and of social collectives (such as states or nations or classes or other social groups)" (125). Theory allows us to speculate.

31 Although the psychology research literature discusses secrecy, it does not often doesn't directly cite Simmel the psychologist.

32 And Georg Simmel before him. 
materials. In addition to first hand accounts and the popular and scholarly literature, agency publications, such as the annual reports of the Information Security Oversight Office's (ISOO), the Public Interest Declassification Board (PIDB) meeting minutes and reports, and FOIA annual reports, which offer students a glimpse into the evolution of government information policies, are included among the readings. The National Security Archive's numerous publications, Project on Government Secrecy's Secrecy News, past editions of Open the Government's Secrecy Report Card, and the American Library Association's Washington Office's historical series Less Access to Less Information add context, critique, and richness. ${ }^{33}$ C-SPAN videos, materials from YouTube, podcasts, NGO reports also provide multiple avenues for exploring secrecy.

In each iteration of the course, I divide the weeks into "themes" such as theoretical foundations, US history, law and regulations, or secrecy at work, the nature of Thompson's democratic secrecy and "necessary secrets," and the uncertain future of openness, transparency, informed consent, and the right to know. ${ }^{34}$ During the first foundational weeks, students are introduced to "conditions of information," or those concepts and problems related to information dissemination and policy, such as secrecy, privacy, confidentiality, censorship, lying, deception, surveillance, and other informationally-connected

33 And many other publications from organizations such as Article 19, POGO, Reporters Committee for Freedom of the Press, Wikileaks, and DDOS (Distributed Denial of Secrets). 34 Simmel never states that secrecy is good or bad; instead, he employs terms such as general, positive, negative, and specific examples to sociologically describe how secrecy, lies, deception, silence, and so on influence relationships. Friedrich utilizes positive and negative in his discussion of secrecy. See also Welty (1996). 
concepts that have in common concealment. ${ }^{35} \mathrm{I}$ find it imperative to highlight the distinctions between "conditions of information" and when they overlap. As this is a LIS/information studies course, I emphasize, for example, the close relationship between secrecy and censorship, and how both act to restrict information of a controversial, embarrassing nature, even though they remain distinct concepts, or "states." I also underscore, for instance, the commonalities between secrecy, privacy, and confidentiality, which are close cousins in terms of their ability to control and conceal information, but are separate conditions. ${ }^{36}$ Definitions of these conditions are harvested from the scholarly literature to illustrate the irregular, often chaotic, understanding of concepts across disciplines and fields. For example, I illustrate this problem through terms such as openness and transparency, which have complex, different meanings depending on the field and discipline. To wit, the research literature is a Tower of Babel when it comes to the discussion of the conditions of information.

Types of secrecy are also addressed in the first few weeks of the course as they are critical to understanding the boundaries of concealment, including the regulatory treatment of secrecy (e.g., confidential business information, trade secrecy). In addition, disfunctional secrecy (Friedrich 1972), pathological secrecy (Aftergood 1999), and the open secret, which may also "obscure wrongdoing and

35 As opposed to the "information disorder" that pathologizes conditions or states of information without investigation into possible positive uses of the information conditions (e.g, Simmel, Friedrich, and others); see Claire Wardle and Hossein Derakhshan (2018), "Thinking About 'Information Disorder': Formats of Misinformation, Disinformation, and Mal-information," In Journalism, "Fake News," \& Disinformation: Handbook for Journalism Education and Training, edited by Cherilyn Ireton and Julie Posetti, 43-54. UNESCO, https://unesdoc.unesco.org/ark:/48223/pf0000265552

36 See also Marx (2001, 2016a, 2016b); Jansen and Martin (2004). 
the darker side of complex organizations" (Adams and Balfour 2011; Leonard $2011,427-428$ ) demonstrate how secrecy is portrayed in the scholarly literature and in the social world. ${ }^{37}$ I stress too the problems with defining and describing a type of secrecy termed government secrecy:

While the depiction of government secrecy as form of regulation and parallel government is useful in understanding significant portions of the secrecy infrastructure and its policies - such as the intelligence community - perhaps even comparatively, as a solid definition of government secrecy, it is lacking. There is no doubt the quantitative work of secrecy illuminates the range of government secrecy; statistics, numerical accounts, and documentation of administrations and agencies are important in profiling how much information is secreted and restricted. This work is valuable in doing comparative work, in developing indicators, benchmarks, and measuring progress toward government transparency. However, these essential activities fall short in chronicling the whole of government secrecy. (Maret 2011b, xv)

I often construct case studies in place of traditional lectures, which highlight the problem of government secrecy within the context of specific US information policies. ${ }^{38}$ Specific cases tie-in with the course readings to provide a multi-faceted exploration into real world policies and practices. ${ }^{39}$ Over time, I've constructed case studies on the Presidential Records Act of 1978 (and controversy over the records of vice-presidents, such as former VP Dick Cheney), notable information policies of presidential administrations that both encouraged and restricted information, the Freedom of Information Act (and difference with the Privacy Act

37Thompson (1999) also makes distinctions between types of secrets: Temporary secrecy can block citizens from knowing about critical aspects of a policy; both accountability and consent is diminished when this occurs. Tacit silence, or a partial secret, is a type of secrecy is somewhere between deep concealment and full disclosure, and based on the philosophy things are better left unsaid (184-86).

38 I often contrast US information policies with those in the UK, EU, and so on.

39 And does double duty in providing understanding of research methods for students unfamiliar with case construction. 
and open records legislation), OGIS, ${ }^{40}$ FOIA and exemptions, the John F. Kennedy Records Act with its creation of an "assassination record," recordkeeping of the National Commission on Terrorist Attacks Upon the United States (9/11

Commission), and the seesaw of security classification and declassification, the latter described as being in the "analog age" (Public Interest Declassification Board 2020 $)^{41}$ offer a concrete view of government secrecy. Depending on the length of the course, I include a case study on the significance of the archive, which includes discussion of the Foreign Relations of the United States, and generally the importance of secrecy and memory in transitional justice, truth commissions, and tribunals. ${ }^{42}$

One model I use to integrate readings, lectures, cases, and discussions is thinking together (Table 3).

Table 3. Thinking Together: A Model for Bringing Secrecy to Light

Thinking together - a template for teaching - is borrowed from philosopher Elizabeth Kamarck Minnich. ${ }^{43}$ I believe, as does Minnich (2003), that "answers do not remain interesting, or become meaningful, if we do not discuss them with other people" (21). What Minnich (2003) offers in this time of polarization, fakery, delayed

history, conspiracy, concealment, and distorted communication is that thinking is "not to be a source of any moral code or set of ethical principles, but a propaedeutic, a preparation for discernment and indeterminate judgment" (20).

40 Office of Government Information Services, which is a "Freedom of Information Act (FOIA) resource for the public and the government. Congress has charged us with reviewing FOIA policies, procedures and compliance of Federal agencies and identifying ways to improve compliance. Our mission also includes resolving FOIA disputes between Federal agencies and requesters." See https://www.archives.gov/ogis.

41 Included in this case study is MDR (Mandatory Declassification Review) and the role of ISCAP (Interagency Security Classification Appeals Panel).

42 See for example, Accatino and Collins 2016, De Baets 2004, Ericson 2005, Gibbs 1996, Jimerson 2009, Schwartz and Cook 2002, and especially Human Rights Watch on archival evidence of atrocities and abuse being removed by social media platforms, https://www.hrw.org/report/2020/09/10/video-unavailable/social-media-platforms-removeevidence-war-crimes

43 I remain grateful that Dr. Minnich served on my doctoral committee. 
Thinking is a social enterprise, and for Minnich (2003), "is exploratory, suggestive; it does not prove anything, or finally arrive anywhere" (20-21). Furthermore, thinking together leads to knowledge as a fusion of information garnered from a variety of sources, "but does not stop"; "practicing thinking that can hold knowledge open, rather than locking it in as unquestionable" (20-21).

For me, Minnich's model of thinking together is a base for the exploration of the unintended consequences of secrecy as an over-relied upon information policy. It

allows students and I to investigate what Philip Melanson (2001) terms the "Machiavellian dimension of the politics of information" (6).

As many of the subjects and cases covered in the course are complex in nature, or as David Perkins' (1999) names it, "conceptually difficult knowledge," thinking together allows for multiple, alternative perspectives that assist in decoding challenging theories and histories.

The disruptive nature of certain histories and policies - often overlooked in undergraduate and some graduate programs - demonstrates that secrecy is not a condition that exists on its own. At times, secrecy is part and parcel of censorship, deception, propaganda, lies, surveillance, sorrow (Commission on Protecting and Reducing Government Secrecy 1997), and horror; as historian David N. Gibbs (2011) observes, "secrecy concerns not only information that might bring shame, disgrace, or dishonor to governments, it is also the most shocking material." 44 These once subterranean histories can be problematic for some students. In this regard, thinking together is a tool for frank discussions as it allows individual students to reflect on how they, as information professionals and citizens, can address and reform practices that further disfunctional secrecy and its cousins. ${ }^{45}$ Stressing intellectual curiosity and courage remind students

44 Such as the Wikileaks' release of "Collateral Murder" and the Abu Ghraib photos, which U.S. District Court for the Southern District of New York Judge Alvin Hellerstein ruled for release: http://www.theguardian.com/us-news/2015/mar/21/abu-ghraib-detainees-photos-federaljudge-rules

45 See David Perkins's (1999) discussion of "troublesome knowledge," particularly inert and 
they are not "neutral" bystanders nor are they alone on their journey. ${ }^{46}$

In closing, this article outlines what I brought to the development and iterations of a government secrecy course. It is my hope this article and others in the special issue of Secrecy and Society spark those in academia to include secrecy as a standalone course or a module within an existing course. Teaching the successes and failures of secrecy in government is not only part and parcel of citizenship, but the human experience. 47

\section{References}

Accatino, Daniela, and Cath Collins. 2016. "Truth, Evidence, Truth: The Deployment of Testimony, Archives and Technical Data in Domestic Human Rights Trials." Journal of Human Rights Practice 8, no. 1: 81-100.

Adams, G. and Balfour, D. (2011), "'Open Secrets": The Masked Dynamics of Ethical Failures and Administrative Evil." In Government Secrecy, Research in Social Problems and Public Policy, 19, edited by Susan Maret, 403-419. Bingley, UK: Emerald Publishing.

Aftergood, Steven. (1999). "Government Secrecy and Knowledge Production: A Survey of Some General Issues." In Secrecy and Knowledge Production, edited by Judith. Reppy, 17-29. Peace Studies Program, Occasional Paper \#23, October, Cornell University. http://large.stanford.edu/publications/crime/references/dennis/occasionalpaper23.pdf

American Library Association. 2019, [2004]. Core Values of Librarianship. http://www.ala.org/advocacy/intfreedom/statementspols/corevalues

Arendt, Hannah. 1972. Crises of the Republic: Lying in Politics, Civil Disobedience on Violence, Thoughts on Politics, and Revolution. New York: Harcourt Brace \& Company.

conceptual knowledge.

46 To riff on Howard Zinn's You Can't be Neutral on a Moving Train (Boston: Beacon Press: 1994) and Paolo Freire's "banking concept of education," where teachers are "depositors" of abstract knowledge to students who memorize and file the "deposits."

47 A nod to Sen. Daniel P. Moynihan's Secrecy, The American Experience (Yale University Press, 1999). 
Best, Joel. 1995. "Typification and Social Problems Construction." In Images of Issues: Typifying Contemporary Social Problems, edited by Joel Best, 3-10. New York: Walter de Gruyter.

Bok, Sissela. 1989 [1983]. Secrets: On the Ethics of Concealment and Revelation. New York: Vintage Books New York: Vintage Books.

Boucheron, Patrick. 2020. Machiavelli: The Art of Teaching People What to Fear. Translated by Willard Wood. New York: Other Press.

Chartered Institute of Library and Information Professionals. n.d. Public Libraries. https://www.cilip.org.uk/page/PublicLibraries

Cohen, Sheldon. 2000. Security Clearances and the Protection of National Security Information Law and Procedures. Defense Personnel Security Research Center, (DTIC) Technical Report 00-4. November. https://apps.dtic.mil/dtic/tr/fulltext/u2/a388100.pdf

Commission on Protecting and Reducing Government Secrecy. 1997. Report of the Commission on Protecting and Reducing Government Secrecy: Hearing before the Committee on Governmental Affairs. United States Senate, 105th Congress, first session, May 7, Washington: Government Printing Office. https://fas.org/sgp/library/moynihan/

Cook, Blanche Wiesen. 1996."Presidential Papers in Crisis Some Thoughts on Lies, Secrets, and Silence." Presidential Studies Quarterly 26, no. 1, 285292.

Darier, Eric. 1999. "Foucault and the Environment." In Discourses of the Environment, edited by Eric Darier, 1-33. Malden, MA: Blackwell.

De Baets, Antoon. 2004. "A Declaration of the Responsibilities of Present Generations Toward Past Generations." History and Theory 43, no. 4: 130164.

Delanty, Gerard, and Aurea Mota. 2017. "Governing the Anthropocene: Agency, governance, knowledge." European Journal of Social Theory 20, no. 1: 9-38.

de Tocqueville, Alexis. 1899. Democracy in America. Translated by Henry Reeve. Revised edition, vol 1. New York: Colonial Press.

DiMario, Michael F. 1997. Prepared Statement Before the Subcommittee on Legislative Branch Appropriations. U.S. Senate on Appropriations Estimates for Fiscal Year 1998.June 5.

http://web.archive.org/web/20170420125036/http://www.gpo.gov/congressi onal/testimony/june97.htm

Ericson, Timothy. 2005. "Building Our Own" Iron Curtain": The Emergence of Secrecy in American Government." The American Archivist 68, no. 1: 18-52.

Fallis, Don. 2009. A Conceptual Analysis of Disinformation. iConference 2009. https://www.ideals. illinois.edu/handle/2142/15205

Fay, Brian. 1987. Critical Social Science: Liberation and its Limits. Ithaca, NY: 


\section{Cornell University Press.}

Federal Research Division. 2018. Disseminating and Preserving Digital Public Information Products Created by the U.S. Federal Government: A Case Study Report. Library of Congress, August. https://www.fdlp.gov/filerepository/about-the-fdlp/superintendent-of-documents-policystatements/3532-final-gpo-frd-digital-case-studies-082218

Foerstel, Herbert N. 1991. Surveillance in the Stacks: The FBI's Library Awareness Program. Westport, CT: Greenwood Press.

Forrester, Jay W. 1965. Industrial Dynamics. Cambridge: MIT Press.

Friedrich, Carl J. (1972). The Pathology of Politics: Violence, Betrayal, Corruption, Secrecy, and Propaganda. New York: Harper \& Row.

Fuller, Steve. 2007. The Knowledge Book: Key Concepts in Philosophy, Science and Culture. New York: Routledge.

Garrison, Alysia E. 2009. "Agamben's Grammar of the Secret Under the Sign of the Law." Law and Critique 20, no. 3: 281-297.

Gerbner, George. 1988. "Telling Stories in the Information Age." In Information and Behavior, edited by Brent D. Ruben, 3-12, vol. 2. New Brunswick, NJ: Transaction Books.

Gibbs, David N. 1996. "Misrepresenting the Congo Crisis." African Affairs 95, no. $380: 453-459$.

. 2011. Sigmund Freud as a Theorist of Government Secrecy. In Government Secrecy, Research in Social Problems and Public Policy, 19, edited by Susan Maret, 5-22. Bingley, UK: Emerald Publishing.

Gotein, Elizabeth. 2016. The New Era of Secret Law. Brennan Center for Justice. https://www.brennancenter.org/our-work/research-reports/new-erasecret-law

Gudmundsdottir, Sigrun. 1995. "The Narrative Nature of Pedagogical Content Knowledge." In Narrative in Teaching, Learning and Research, edited by Hunter McEwan and Kieran Egan, 24-38. New York: Teachers College Press.

Haskell, Thomas L. 1998. Objectivity is Not Neutrality: Explanatory Schemes in History. Baltimore, MD: Johns Hopkins University Press.

International Federation of Library Associations and Institutions. 2019. Access by Right - 20 Years of the IFLA Statement on Libraries and Intellectual Freedom. https://www.ifla.org/node/92405

Jackson, Michael. 2013. The Politics of Storytelling: Variations on a Theme by Hannah Arendt. Vol. 4. Copenhagen: Museum Musculanum Press, University of Copenhagen.

Jacobs, James R. 2019. "'Issued for Gratuitous Distribution'"- The History of Fugitive Documents and the FDLP." Against the Grain 29, no. 6: 5. 
Janoski, Thomas, and Brian Gran. 2002. "Political Citizenship: Foundations of Rights." In Handbook of Citizenship Studies, edited by Engin F. Isin and Bryan S. Turner, 13-52. Thousand Oaks, CA: SAGE.

Jansen, Sue Curry, and Brian Martin. 2004. "Exposing and Opposing Censorship: Backfire Dynamics in Freedom-of-Speech Struggles." Pacific Journalism Review 10 no.1: 29-45. https://ojs.aut.ac.nz/pacific-journalismreview/article/view/777/978

Jimerson, Randall C. 2009. Archives Power: Memory, Accountability, and Social Justice. Chicago: Society of American Archivists.

Kerry, John. 1997. "Growing Intelligence Budgets." Congressional Record, May 1, S3891-S3894. https://www.fas.org/sqp/congress/kerry.html

Leonard, William J. 2011. "The Corrupting Influence of Secrecy on National Policy Decisions." In Government Secrecy Research in Social Problems and Public Policy, 19, edited by Susan Maret, 421-434. Bingley, UK: Emerald Publishing.

Lerud, Joanne V., and Lisa G. Dunn. 1997. Fugitive Information on the World Wide Web: A Cost-effective Method of Access for a Diverse Clientele." IATUL Proceedings, University Library of Trondheim, Norwegian University of Science and Technology, June 30-July 4. https://docs.lib.purdue.edu/cgi/viewcontent.cgi?article=1399\&context=iatul

McDonald, Deirdre. 2011.The Spooks in the Stacks: Academic Libraries and the National Security State Since 9/11. In The CIA on Campus: Essays on Academic Freedom and the National Security State, edited by Philip Zwerling, 88-112. Jefferson, NC: McFarland.

Maret, Susan, ed. 2011a. Government Secrecy. Research in Social Problems and Public Policy 19. Howard House, UK: Emerald Publishing.

. 2011b. "Introduction: Government Secrecy." In Government Secrecy, Research in Social Problems and Public Policy, 19, edited by Susan Maret, xixxx. Bingley, UK: Emerald Publishing.

. 2013. "Freudenburg Beyond Borders: Recreancy, Atrophy of Vigilance, Bureaucratic Slippage, and the Tragedy of 9/11. In Gedenkschrift in Honor of William R. Freudenburg, a Life in Social Research. Research in Social Problems and Public Policy 21, edited by Susan Maret, 201-223. Bingley, UK: Emerald Publishing.

.2014a. "Intellectual Freedom and Government Secrecy." In The Library Juice Press Handbook of Intellectual Freedom: Concepts, Cases, and Theories, edited by Mark Alfino and Laura Koltutsky, 247-281. Sacramento: Library Juice Press.

. 2014b. The Moynihan Commission's Secrecy by Regulation and its Value to Environmental Sociology. Sociological Imagination 50, no. 2: 105-137. . 2016. "The Charm of Secrecy: Secrecy and Society as Secrecy Studies." 
Secrecy and Society 1, no. 1, 1-30.

https://scholarworks.sjsu.edu/secrecyandsociety/vol1/iss1/1/

. 2018. Murky Projects and Uneven Information Policies: A Case Study of

the Psychological Strategy Board and CIA. Secrecy and Society 1, no.2.

http://scholarworks.sjsu.edu/secrecyandsociety/vol1/iss2/6/

Maret, Susan, and Jan Goldman, eds. 2009. Government Secrecy: Classic and Contemporary Readings. Westport, CT: Libraries Unlimited.

Marx, Gary T. 2001. "Censorship and Secrecy, Social and Legal Perspectives."

In International Encyclopedia of the Social and Behavioral Sciences, edited

by Neil J. Smelser and Paul B. Baltes. Saint Louis, England: Elsevier.

. 2016a. "Humpty Dumpty Was Wrong-Consistency in Meaning Matters:

Some Definitions of Privacy, Publicity, Secrecy, and Other Family Members."

Secrecy and Society 1, no. 1: 3.

https://scholarworks.sjsu.edu/secrecyandsociety/vol1/iss1/3/

. 2016b.Windows into the Soul: Surveillance and Society in an Age of High

Technology. Chicago: University of Chicago Press.

Maxwell School of Syracuse University. 2003. National Security and Open

Government: Striking the Right Balance. Campbell Public Affairs Institute.

https://archive.org/details/maxwell natlsecopengov

Melanson, Philip H. 2001. Secrecy Wars: National Security, Privacy, and the Public's Right to Know. Washington, DC: Brassey's Inc.

Minnich, Elizabeth Kamarck. 2003. "Teaching Thinking: Moral and Political considerations." Change: The Magazine of Higher Learning 35, no. 5: 18-24.

Mooney, Linda A., David Knox, and Caroline Schacht. 2013, [2011].

Understanding Social Problems. 8th ed. Belmont, CA: Wadsworth Cengage Learning.

Moore, Nick. 1998. "Rights and Responsibilities in an Information Society." Journal of Information, Law and Technology 1.

https://warwick.ac.uk/fac/soc/law/elj/jilt/1998 1/moore/

National Commission on Libraries and Information Science. 1988 [1987]. Hearing on Sensitive But Not Classified Information. Library of Congress: Washington, DC.

Paley, Karen. 2001. I-Writing: The Politics and Practice of Teaching First-Person Writing. Carbondale: Southern Illinois University Press.

Perkins, David. 1999. "The Many Faces of Constructivism." Educational Leadership 57, no. 3: 6-11.

Pitard, Jayne. 2017. "A Journey to the Centre of Self: Positioning the Researcher in Autoethnography." Forum Qualitative Sozialforschung/Forum: Qualitative Social Research, 18, no. 3. http://dx.doi.org/10.17169/fqs18.3.2764. 
Popper, Karl R. 1962. Conjectures and Refutations: The Growth of Scientific Knowledge. New York: Basic Books.

Public Interest Declassification Board. 2020. A Vision for the Digital Age: Modernization of the U.S. National Security Classification and Declassification System. May. https://www.archives.gov/declassification/pidb/recommendations

Raskin, Marcus G., and Robert Spero. 2007. The Four Freedoms: The Clear and Present Danger from Our National Security State. Westport, CT: Praeger.

Reed-Danahay, Deborah. 2009. "Anthropologists, Education, and Autoethnography." Reviews in Anthropology 38, no. 1: 28-47.

Reppy, Judith, ed. 1999. Secrecy and Knowledge Production. Cornell University, Occasional Paper \#23. https://archive.org/details/reppy secrecyknowledge

Roberts, Alasdair S. 2004. "National Security and Open Government." Georgetown Public Policy Review 9: 69-85.

Rudesill, Dakota S. 2015. "Coming to Terms with Secret Law." Harvard National Security Journal 7: 241-390.

Schlesinger Jr., Arthur M. 1973. The Imperial Presidency. New York: Atlantic Monthly.

Schöpfel, Joachim. 2010. Towards a Prague Definition of Grey Literature. Twelfth International Conference on Grey Literature, National Technical Library, Prague, Czech Republic, December 6-7. http://www.textrelease.com/images/GL12 Abstract S1N1.pdf

Schwartz, Joan M., and Terry Cook. 2002. "Archives, Records, and Power: The Making of Modern Memory." Archival Science 2: 1-19.

Scott, Craig. Anonymous Agencies, Backstreet Businesses, and Covert Collectives: Rethinking Organizations in the 21st Century. Stanford, CA: Stanford University Press, 2013.

Simmel, Georg. 1906. "The Sociology of Secrecy and of Secret Societies." American Journal of Sociology 11, no. 4: 441-498. https://www.journals.uchicago.edu/doi/pdfplus/10.1086/211418

Starr, Joan. 2004. "Libraries and National Security: An Historical Review." First Monday 9, no. 12.

https://firstmonday.org/ojs/index.php/fm/article/download/1198/1118

Stasavage, David. 2020. The Decline and Rise of Democracy: A Global History from Antiquity to Today. Princeton, NJ: Princeton University Press.

Strauss, Peter L. 2020. How the Administrative State Got to This Challenging Place. https://scholarship.law.columbia.edu/faculty scholarship/2669

Tesich, Steve. 1992. "A Government of Lies." The Nation 254, no. 1: 12-14. Thompson, Dennis F. 1999. "Democratic Secrecy." Political Science Quarterly 
114, no. 2: 181-193.

Uotinen, Johanna. 2011. "Senses, Bodily Knowledge, and Autoethnography:

Unbeknown Knowledge from an ICU Experience." Qualitative Health Research 21, no. 10: 1307-1315.

US National Commission on Libraries and Information Science. 1988 [1987]. Hearing on Sensitive But Not Classified Information. Washington, DC: US National Commission on Libraries and Information Science

Wall, Sarah. 2006. "An Autoethnography on Learning about Autoethnography." International Journal of Qualitative Methods 5, no. 2: 146-160.

Watts, Michael. 2008. "Narrative Research, Narrative Capital, Narrative Capability." In Talking Truth, Confronting Power, edited by Jerome Satterthwaite, Michael Watts, and Heather Piper, 99-112. Sterling, VA: Trentham Books.

Welty, Gordon. 1996. "Simmel on 'The Lie.'" S: European Journal for Semiotic Studies 7, no. 2: 273-98.

White, Luise. 2000. Telling More: Lies, Secrets, and History. History and Theory 39 , no. 4, 11-22.

Wilhelm, Jeff. 2013. "Opening to Possibility: Reflectivity and Reflexivity in Our Teaching." Voices from the Middle 20, no. 3: 57-59.

Wise, David. 1973. The Politics of Lying. New York: Random House.

Wolff, Kurt H., ed. 1950. The Sociology of Georg Simmel. New York: Free Press.

Yankelovich, Daniel. 1991. Coming to Public Judgment: Making Democracy

Work in a Complex World. New York: Syracuse University Press. 